Acta vet. scand. $1969,10,299-308$.

From the Department of Reproductive Physiology and Pathology, Veterinary College of Norway, Oslo.

\title{
IMMUNOLOGICAL PREGNANCY DIAGNOSIS IN THE MARE
}

\author{
By \\ Amund Wormstrand
}

In the mare an accurate and early pregnancy diagnosis is of considerable importance. Rectal and vaginal exploration, blood tests, and urine tests are the methods in common use. The blood lests are the bioassay of gonadotropic hormones with the aid of mice and rats (Ashheim \& Zondek 1928, Cole \& Hart 1930) or rabbits (Friedman \& Lapham 1931, Schneider 1932).

Immunological diagnosis of pregnancy in mares was first attempted by Wide \& Wide (1963) using the agglutination test similar to the test routinely utilized when diagnosing pregnancy in women. Wide $\&$ Wide seemed to obtain good results, but other workers (Oliva 1963, Ikemoto et al. 1964, 1965) were less successful owing to nonspecific agglutination caused by mare sera.

Ikemoto et al. $(1964,1965)$ and Leclerq \& Derivaux (1964) showed that PMSG contained an $\alpha$-globulin soluble in perchloric acid which precipitated with rabbit serum anti-PMSG absorbed with normal mare serum (NMS). The specificity of this precipitation reaction, however, was too low to be suitable for pregnancy diagnosis (King 1965).

In 1967, Richards injected turkeys with PMSG and produced antisera where the ratio of anti-PMSG to antibodies to impurity antigens was much higher than in the corresponding mammalian preparations. Using turkey anti-PMSG he got excellent results with the gel-precipitation method.

The present investigation is an attempt to further test the reliability and sensitiveness of Richards' method, to compare it with the A.-Z. test, and to adapt this method to normal routine testing. 


\section{MATERIALS AND METHODS}

The pregnancy test described by Richards is based on the precipitation of PMSG with turkey serum anti-PMSG in Ouchterlony plates. The level of PMSG in the serum of a pregnant mare is not high enough to give a visible precipitation line until about 60 days after service. Richards therefore made use of the polygonplate method of analysis (Hayward \& Augustin 1957, Richards 1967, Coombs et al. 1963).

After several trials with Richards' method the following technique was found to be the most simple and accurate.

Glass plates $8.5 \mathrm{~cm}$ square (kept in alcohol) are covered with $7 \mathrm{ml} 1.7 \%$ agar containing $9 \% \mathrm{NaCl}$ and $0.1 \%$ sodium acid giving an approximately $1.2 \mathrm{~mm}$ thick agar layer. The agar plates are kept in airtight plastic boxes with some moistened foam plastic in the bottom to keep the agar from drying. The agarplates are allowed to age for several hours in a refrigerator. After the ageing or just before use, holes are cut in the agar after the pattern shown in Fig. 1. The holes are stamped out with a $4 \mathrm{~mm}$ corkborer and a template with corresponding holes, the plugs are lifted out on the tip of a scalpel. To ensure sharp precipitation lines, the distance between the center well and the surround-

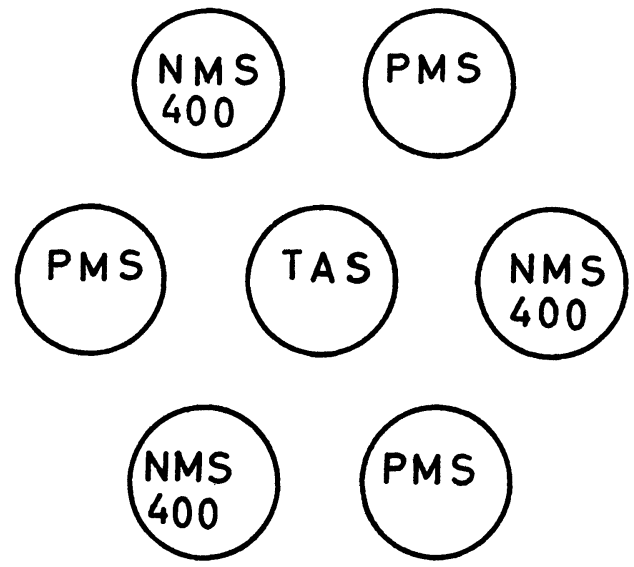

Figure 1. The arrangement of the wells and the distribution of the test sera.

NMS

NMS
400

PMS = The mare serum to be tested.

TAS = Turkey serum anti-PMSG. 
ing wells is kept at approximately $3 \mathrm{~mm}$. The agar plates may be stored for at least 14 days in a refrigerator before use. The glass plates may be autoclaved, washed and used in later tests.

When a test is about to be made alternating wells are filled with one drop of test serum and one drop of normal mare serum (NMS) with 400 i. u. PMSG as in Fig. 1. The center well is filled with turkey serum. The plates are placed in the boxes and kept at room temperature for 24 to $48 \mathrm{hrs}$. The NMS with 400 i.u. PMSG will then give a strong precipitation line with the turkey serum (Fig. 2). Test sera containing over 2.5 i.u. PMSG will cause a deviation of the precipitation lines that becomes more marked with increasing contents of PMSG.

The blood samples were drawn from mares of the two Norwegian trotting breeds, - the warmblooded (standard bred) trotter and the Norwegian trotter, a light coldblooded horse. As a control a modified A.-Z. test (using immature rats instead of

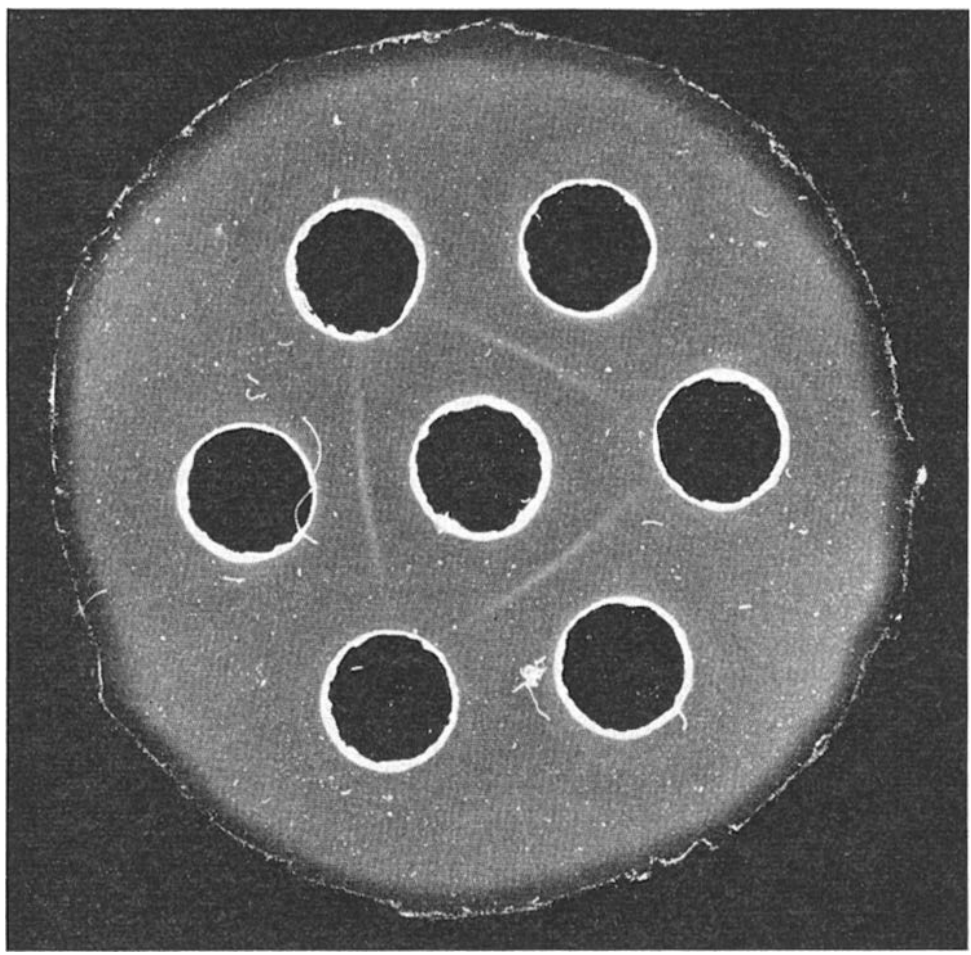

Figure 2. Serum from a non-pregnant mare. The precipitation lines are formed between the wells containing NMS 400 and the center well. 


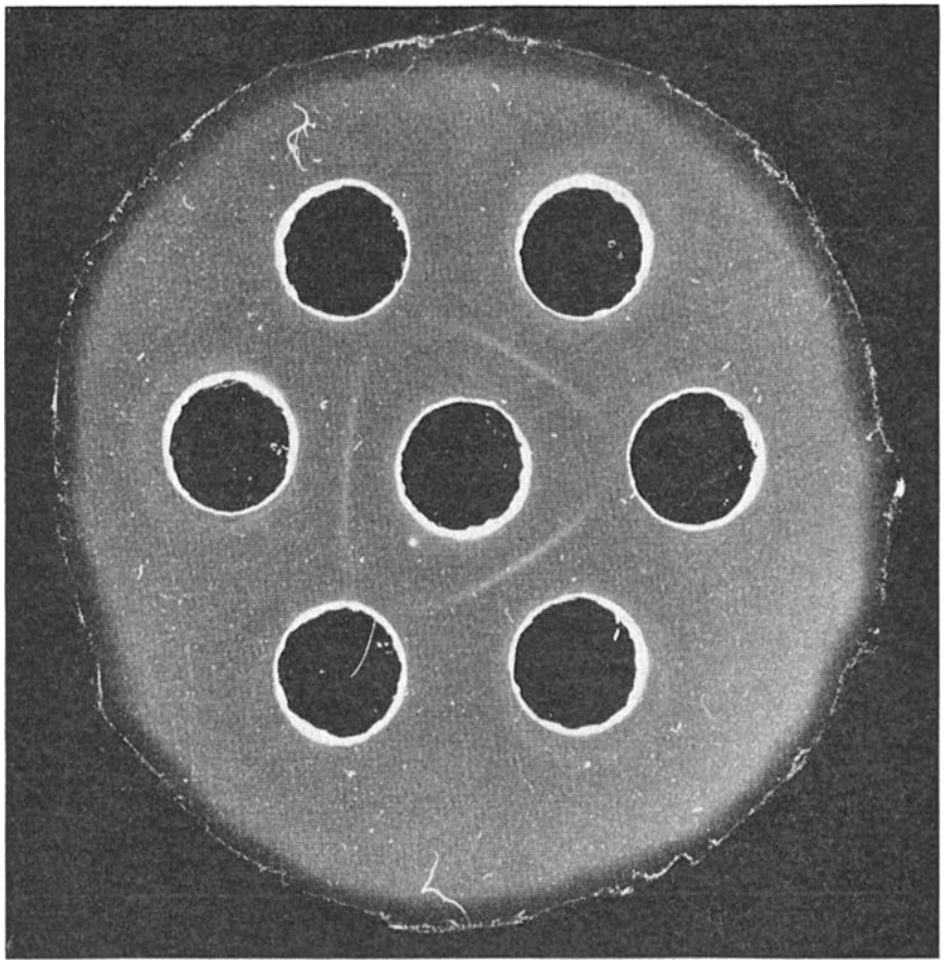

Figure 3. Serum from a pregnant mare 41 days after the last service.

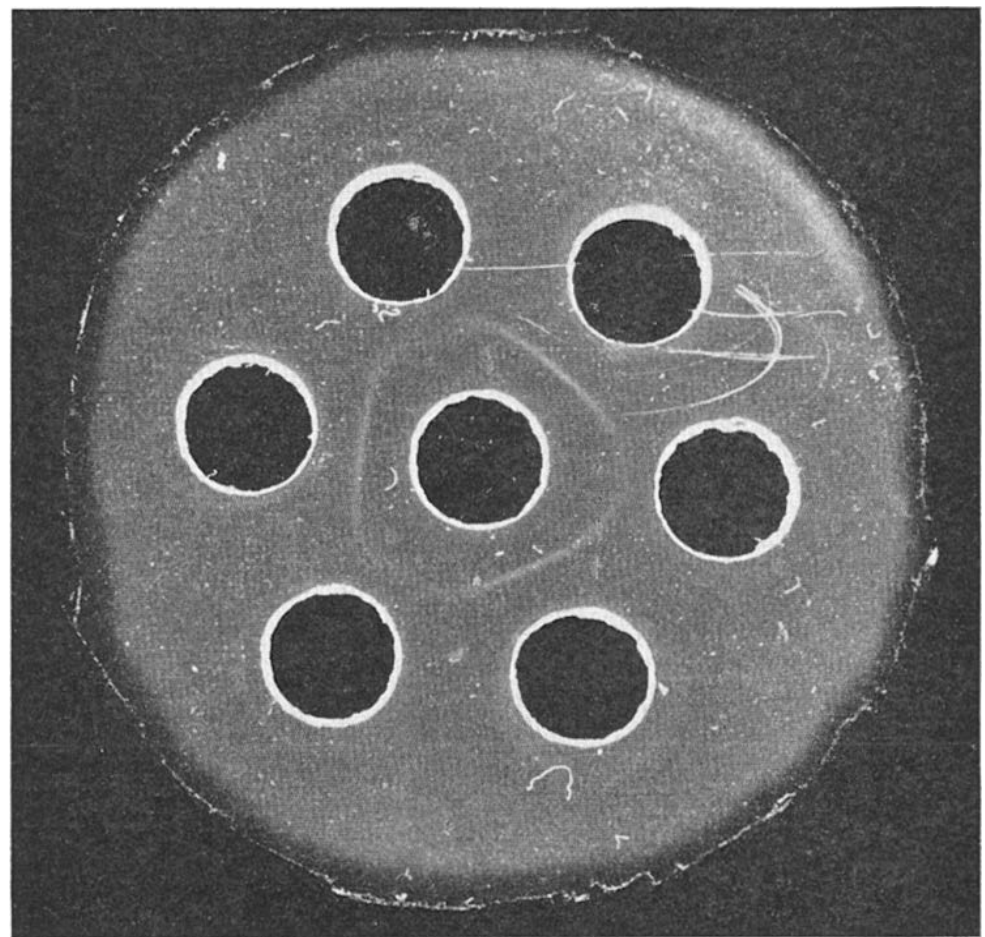

Figure 4. Serum from a pregnant mare 46 days after the last service. 


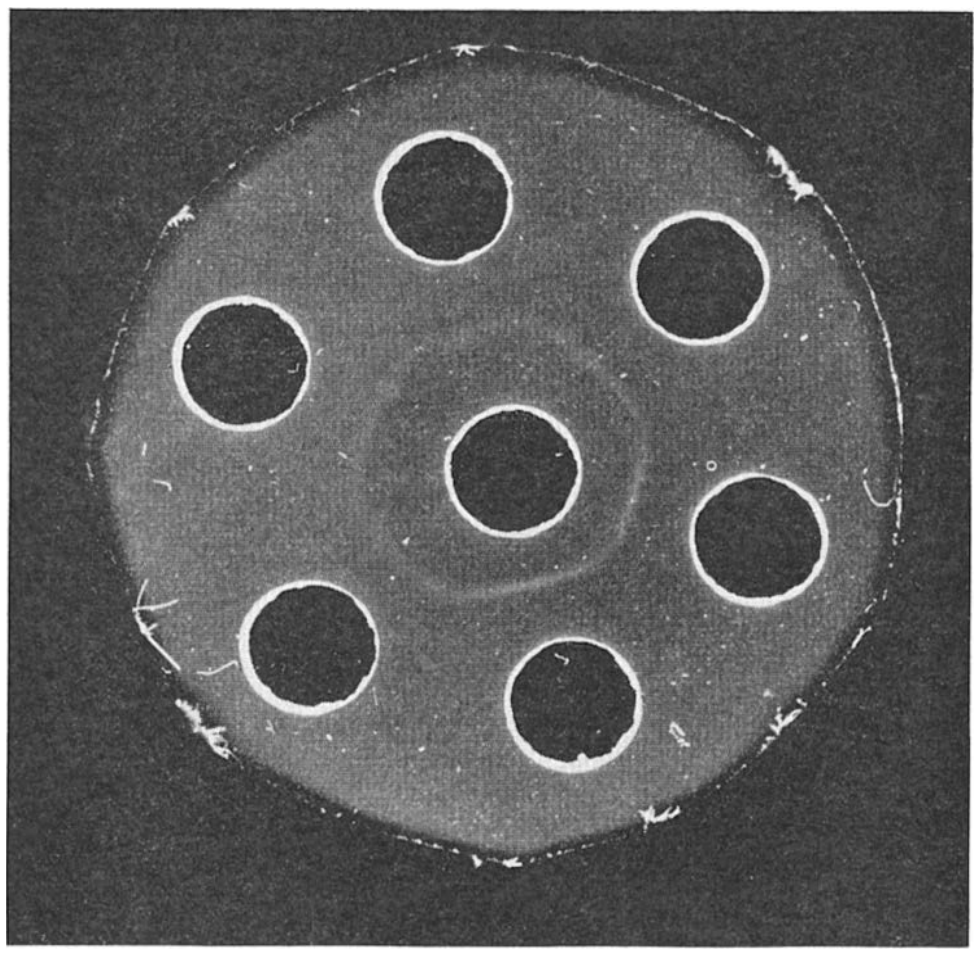

Figure 5. Serum from a pregnant mare 61 days after the last service.

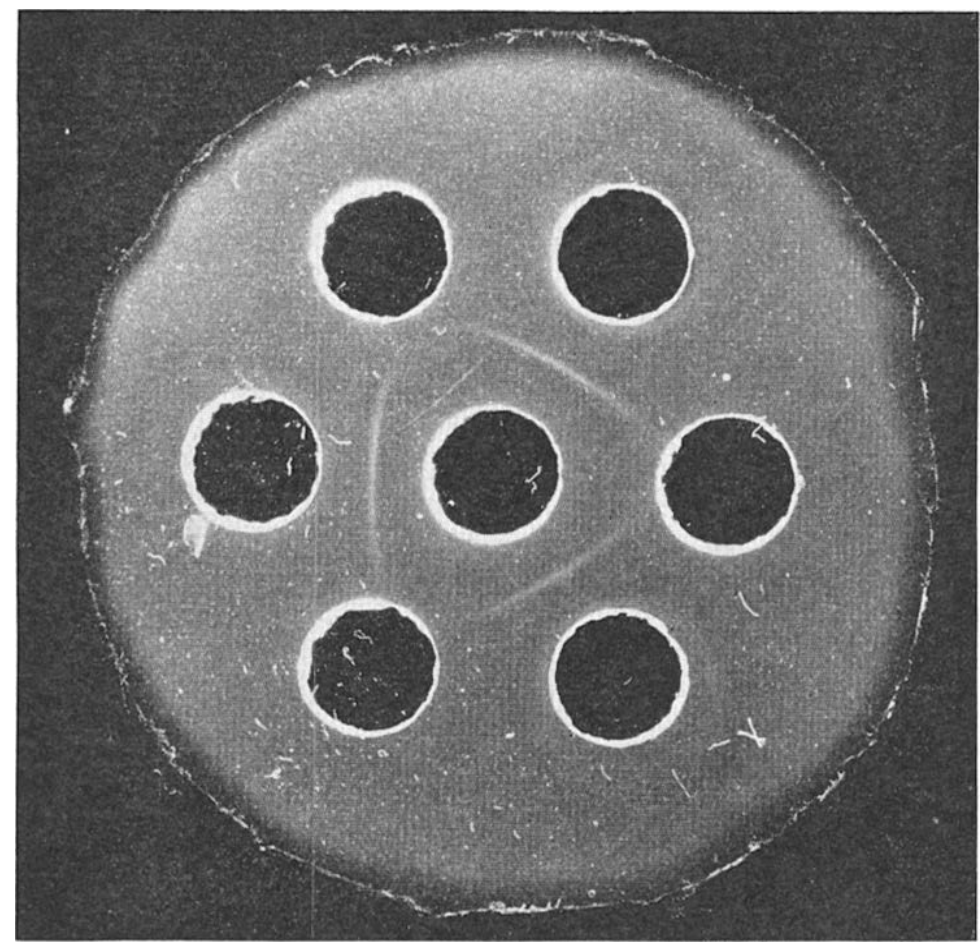

Figure 6. Serum from a pregnant mare 108 days after the last service. 
mice) was made on almost every sample, and in most cases rectal exploration and vaginal examination were also made. Rectal exploration and bloodsampling were, if possible, made by others than the author, so that the observations of the results of the gel-diffusion test would be made with an unbiased mind.

\section{RESULTS}

In total 56 samples from 50 different mares 37 to 108 days after the last services were tested. All were clinically examined, and 52 samples from 48 mares were also tested with the A.-Z. test. Thirtyfive samples were taken at or before the 50th day, and 21 samples between 50 and 108 days.

Figs. 2-6 illustrate the precipitation lines formed by sera in different stages of early pregnancy. The change from a negative to a feebly positive reaction is almost imperceptible. In Fig. 4 a clearly positive reaction is shown. The development from a feebly positive reaction to a clearly positive one is fairly rapid. When the PMSG-level is at its maximum, precipitation lines will be formed between the center well and all the surrounding wells, thus making a hexagon (Fig. 5).

In Table 1 the results of the testing for each mare are shown. In the first testing of mare no. 5, the A.-Z. test was nonspecific (a new sample was requested), while the immunological method was negative. The mare was later found to be nonpregnant. This

Table 1. Results of immunological, Ashheim-Zondek and clinical examinations of 50 mares.

\begin{tabular}{|c|c|c|c|c|}
\hline Mare no. & Days & Immunol. & A.-Z. & Clinic \\
\hline 1 & 37 & -- & & + \\
\hline 17 & 42 & $\ldots$ & - & - \\
\hline 20 & , & - & - & - \\
\hline 44 & , & - & - & - \\
\hline 5 & 45 & - & $(+)$ & - \\
\hline 41 & , & - & - & - \\
\hline 48 & 46 & - & - & - \\
\hline 2 & 47 & - & & - \\
\hline 11 & , & - & - & - \\
\hline 22 & " & - & - & + \\
\hline 46 & 48 & - & - & - \\
\hline 47 & , & - & - & - \\
\hline 49 & , & - & - & - \\
\hline 20 & 49 & - & - & - \\
\hline
\end{tabular}


Table 1 (continued).

\begin{tabular}{|c|c|c|c|c|}
\hline Mare no. & Days & Immunol. & A.-Z. & Clinic. \\
\hline 9 & 50 & - & - & - \\
\hline 33 & 51 & - & - & - \\
\hline 32 & 57 & - & - & - \\
\hline 38 & 60 & - & - & pyom. \\
\hline 5 & 66 & - & - & - \\
\hline 8 & 80 & - & - & - \\
\hline 34 & 40 & + & + & + \\
\hline 12 & 41 & + & + & + \\
\hline 13 & ” & + & + & + \\
\hline 6 & 42 & + & + & + \\
\hline 19 & ” & + & + & + \\
\hline 14 & 43 & + & + & + \\
\hline 3 & 44 & + & + & + \\
\hline 24 & , & + & + & + \\
\hline 27 & ” & + & + & + \\
\hline 30 & , & + & + & + \\
\hline 15 & 45 & + & + & + \\
\hline 26 & " & + & + & + \\
\hline 29 & ” & + & + & + \\
\hline 7 & 46 & + & + & + \\
\hline 16 & ", & + & + & + \\
\hline 23 & , & + & + & + \\
\hline 42 & 48 & + & + & + \\
\hline 4 & 50 & + & + & + \\
\hline 31 & , & + & + & + \\
\hline 36 & ", & + & + & + \\
\hline 18 & 51 & + & + & + \\
\hline 25 & , & + & + & + \\
\hline 40 & ” & + & + & + \\
\hline 1 & 52 & + & & + \\
\hline 37 & 56 & + & + & + \\
\hline 45 & 57 & + & + & + \\
\hline 21 & 60 & + & + & + \\
\hline 28 & 61 & + & + & + \\
\hline 22 & " & + & + & + \\
\hline 39 & " & + & + & + \\
\hline 50 & 62 & + & + & + \\
\hline 35 & 69 & + & + & + \\
\hline 10 & 70 & + & + & + \\
\hline 15 & 75 & + & + & + \\
\hline 43 & 80 & + & + & + \\
\hline 15 & 108 & + & & + \\
\hline
\end{tabular}


was the only case where the results of the two methods differed. With the immunological method no false positive reaction occurred. Both methods, however, were negative in one case (mare no. 22) where vaginal examination and rectal exploration proved the mare to be pregnant. This serum was drawn as late as 47 days after the last service. The result of the clinical examination was confirmed at 61 days, so the possibility of early embryonic death was excluded. Blood samples drawn at this day were also positive with both tests.

With the exception of mare no. 1 at 37 days and mare no. 22 at 47 days, the immunological method gave the correct answers; the earliest positive reaction obtained was at 40 days (mare no. 34).

For the period between 40 and 50 days this gives $97.1 \%$ accuracy for the immunological method. Between 51 and 100 days the accuracy is $100 \%$. Totally the accuracy is $96.4 \%$. For the Ashheim-Zondek test the corresponding figures are $94.1 \%$, $100 \%$ and $94.6 \%$.

\section{DISCUSSION AND CONCLUSION}

The blood samples that have been used in this investigation represent what a laboratory normally receives for pregnancy diagnosis. No attempt has been made to draw the blood earlier in the pregnancy than required for the Ashheim-Zondek test.

Discrepancies in the results of the pregnancy test and the number of foals born, are eliminated in this investigation, since the mares have been tested clinically for pregnancy. This is considered to be the best way to test the laboratory methods. It is no inaccuracy of the blood tests if a pregnant mare aborts later on.

The time when PMSG is detectable in a pregnant mare's serum seems to vary somewhat, it is therefore recommended to draw the blood samples at about 45 days to exclude most of the false negative results. The biological variance in the test animals and the degree of unreliability always present when animals are used in biological tests tend to give the immunological method a greater accuracy and reliability than the A.-Z. method. If abortions are excluded it does not seem possible to get a false positive reaction with the gel-diffusion test.

The procedures of the immunological method are very simple, no great amount of learning is needed, only the reading of the 
results needs some practice. The method is very cheap and needs very little room. It should even be possible for a general practitioner, with some amount of horsework, to make use of it.

Moreover, this method does not necessitate the killing of test animals which is comparatively costly.

As a routine test for the diagnosis of pregnancy in mares this investigation indicates that the immunological method of Richards is to be preferred to the Ashheim-Zondek and Friedman-Schneider methods.

\section{ACKNOWLEDGMENTS}

The author wishes to express his thanks to Dr. C. B. Richards for providing the turkey serum anti-PMSG, and to the Department of Pharmacology and Toxicology, head Professor Dr. O. Dybing, for making the Ashheim-Zondek tests.

\section{REFERENCES}

Ashheim, S. \& B. Zondek: Die Schwangerschaftsdiagnose aus Harn durch Nachweis des Hypophysen-Vorderlappenhormons. (The pregnancy diagnosis by estimating the hormone of the anterior hypophysis in the urine). Klin. Wschr. 1928, 7, 1404-1411.

Cole, H. H. \& G. Hart: The potency of blood serum of mares in progressive stages of pregnancy in effecting the sexual maturity of the immature rat. Amer. J. Physiol. 1930, 93, 57-68.

Coombs, R. R. A., C. B. Richards \& B. Dodd: Serological identification of seminal stains. Med. Sci. Law 1963, 3, 65-70.

Friedman, M. H. \& M. E. Lapham: A simple, rapid procedure for the laboratory diagnosis of early pregnancies. Amer. J. Obstet. Gynec. 1931, 21, 405-410.

Hayward, B. J. \& R. Augustin: Quantitative gel diffusion methods for assay of antigens and antibodies. Int. Arch. Allergy 1957, 11, $192-196$.

Ikemoto, S., H. Mukoyama, S. Suzuki \& T. Furuhata: Immunological studies of pregnant mare serum gonadotropin I. Proc. Jap. Acad. 1964, 40, 679-682.

Ikemoto, S., H. Mukoyama, S. Suzuki \& T. Furuhata: Immunological studies of pregnant mare serum gonadotropin II. Proc. Jap. Acad. 1965, 41, 428-432.

King, J. M.: Comparative Aspects of Reproduction in Equidae. Thesis, Univ. Cambridge 1965.

Leclerq, M. \& J. Derivaux: Diagnostic immuno-chimique de la gestation chez la jument. (Inmuno-chemical pregnancy diagnosis in the mare). Bull. Acad. vet. Fr. 1964, 37, 47-53.

Oliva, O.: Richerche immunologiche sulla gonadotropina serica equina. (Immunological research of pregnant mare serum gonadotropin). Atti Soc. ital. Sci. vet. 1963, 17, 369-376. 
Richards, C. B.: Simple immunological method for the diagnosis of pregnancy in mares. Nature (Lond.) 1967, 215, 1280-1281.

Schneider, P. F.: The modified Ashheim-Zondek test. Amer. J. Obstet. Gynec. 1932, 24, 174-178.

Wide, M. \& L. Wide: Diagnosis of pregnancy in mares by an immunological method. Nature (Lond.) 1963, 198, 1017-1018.

\section{SUMMARY}

An immunological gel-diffusion test for the diagnosis of pregnancy in the mare is described. 56 blood samples from 50 different mares were tested. Control tests were made both by the AshheimZondek method and by clinical examination.

The accuracy of the immunological method was $96.4 \%$. No false positive reactions were observed. It is recommended to draw the blood sample at approximately 45 days or more after the last service.

The immunological method is simple, cheap and accurate and is recommended as a routine test for the diagnosis of pregnancy in mares.

\section{ZUSAMMENFASSUNG}

Immunologische Trächtigkeitsdiagnostik bei der Stute.

Eine immunologische Gel-diffusionsmethode für die Trächtigkeitsdiagnostik bei der Stute wird dargestellt.

Das Material umfasst 56 Blutproben aus 50 verschiedenen Stuten. Kontrollproben wurden mit der Ashheim-Zondek Methode und mit klinischer Untersuchung untergenommen.

Die immunologische Methode gab total eine Sicherheit auf 96,4\%. Keine falsche positive Reaktionen wurden observiert. Es wird empfohlen die Blutprobe bei etwa 45 Tagen oder mehr nach der letzten Bedeckung zu nehmen.

Die immunologische Methode ist einfach, billig und sicher und wird für das Routinearbeit mit Trächtigkeitsdiagnostik bei der Stute empfohlen.

\section{SAMMENDRAG}

Immunologisk drektighetsdiagnostikk hos hoppe.

Det beskrives en immunologisk gel-diffusjonsmetode for drektighetsdiagnostikk hos hoppe. 56 blodpr $\varnothing v e r$ fra 50 forskjellige hopper er unders $\varnothing \mathrm{kt}$. Kontrollpr $\varnothing$ ver ble foretatt bảde med Ashheim-Zondeks metode og ved klinisk unders $\varnothing$ kelse.

Den immunologiske metode ga totalt 96,4\% sikkerhet. Det var ingen falske positive reaksjoner. Blodpr $\varnothing$ ven b $\emptyset \mathrm{r}$ taes ca. $45 \mathrm{~d}$. eller mer etter siste bedekning.

Den immunologiske metode er enkel, billig og sikker, og anbefales brukt $\mathrm{i}$ rutinearbeidet med drektighetsdiagnostikk hos hoppe. 